Asian Fisheries Science 23 (2010):591-605

(C) Asian Fisheries Society

ISSN 0116-6514

E-ISSN: 2073-3720

https://doi.org/10.33997/j.afs.2010.23.4.012

\title{
An integrated approach to sustainable shrimp farming
}

\author{
Shaun M. Moss", Dustin R. Moss, Clete A. Otoshi and Steve M. Arce
}

Oceanic Institute, Waimanalo, Hawaii USA

\begin{abstract}
An estimated 3.4 million metric tons of farmed shrimp were produced globally in 2008 and crop value was estimated at more than US $\$ 14$ billion. Despite the economic importance of farmed shrimp, the shrimp farming industry has been slow to adopt biosecurity and genetic improvement strategies which are prevalent in more mature meat-producing industries. However, this trend is changing rapidly. Historically, the giant tiger prawn, Penaeus monodon has been the most common shrimp species cultured in Asia. Now, most Asian shrimp farmers stock their ponds with non-indigenous Pacific white shrimp, Litopenaeus vannamei. There are a number of advantages in culturing $L$. vannamei over $P$. monodon, including the availability of healthy and domesticated stocks. Commercially available populations of specific pathogen free (SPF) L. vannamei exist in the Americas and Asia and these populations are free of such pathogens as white spot syndrome virus (WSSV) and Taura syndrome virus (TSV). Another significant advantage in culturing L. vannamei is the opportunity to benefit from selective breeding. Commercially available populations of this species have been bred for rapid growth and enhanced TSV resistance over multiple generations. Despite the benefits of culturing healthy and selectively bred L. vannamei, there are significant challenges. For example, the genetic potential of these shrimp cannot be fully realized if they are grown in environments where virulent pathogens exist. Farmers using selectively bred shrimp need to adopt costeffective, biosecure strategies to mitigate the risk of pathogen introduction into their growout ponds. In addition, care must be taken by shrimp breeders to ensure that founder stocks come from genetically diverse populations in order to mitigate problems associated with inbreeding depression. The sustainability of the global shrimp farming industry will be predicated on the use of genetically diverse and selectively bred populations of SPF shrimp stocked in biosecure environments.
\end{abstract}

\section{Introduction}

Historically, the giant tiger prawn, $P$. monodon has been the most common shrimp species cultured in Asia. However, about a decade ago, an increasing number of Asian farmers began stocking their ponds with non-indigenous Pacific white shrimp, $L$. vannamei and the dominance of P. monodon started to fade. In 2000, an estimated

$\overline{\text { *Corresponding author. E-mail address: smoss@ oceaninstitute.org }}$ 
630984 metric tons (MT) of farmed P. monodon were produced globally, whereas only 145386 MT of farmed L. vannamei were produced during the same year (Fig. 1, FAO 2010). However, farmed L. vannamei production increased to 2259183 MT in 2008 and this represents a $1454 \%$ increase over eight years. During the same period, farmed production of $P$. monodon increased to 721867 MT representing only a $14 \%$ increase. This dramatic species shift occurred primarily in Asia where more L. vannamei are now produced than in the Western Hemisphere.

The historical dominance of $P$. monodon in Asia can be attributed to a number of factors including the availability of gravid female broodstock from local waters, rapid growth of juveniles in ponds and the ability of this species to grow to a relatively large size. However, over the past decade, the availability and quality of wild broodstock have declined and many Asian farmers have observed poor growth and survival of $P$. monodon in their ponds, resulting in decreased production and profitability. Poor pond performance was attributed, in part, to bacterial and viral pathogens which are ubiquitous in the major shrimp farming regions of Asia. Because of declining profit margins associated with culturing $P$. monodon, shrimp farmers in Asia began exploring other options including the culture of $L$. vannamei.

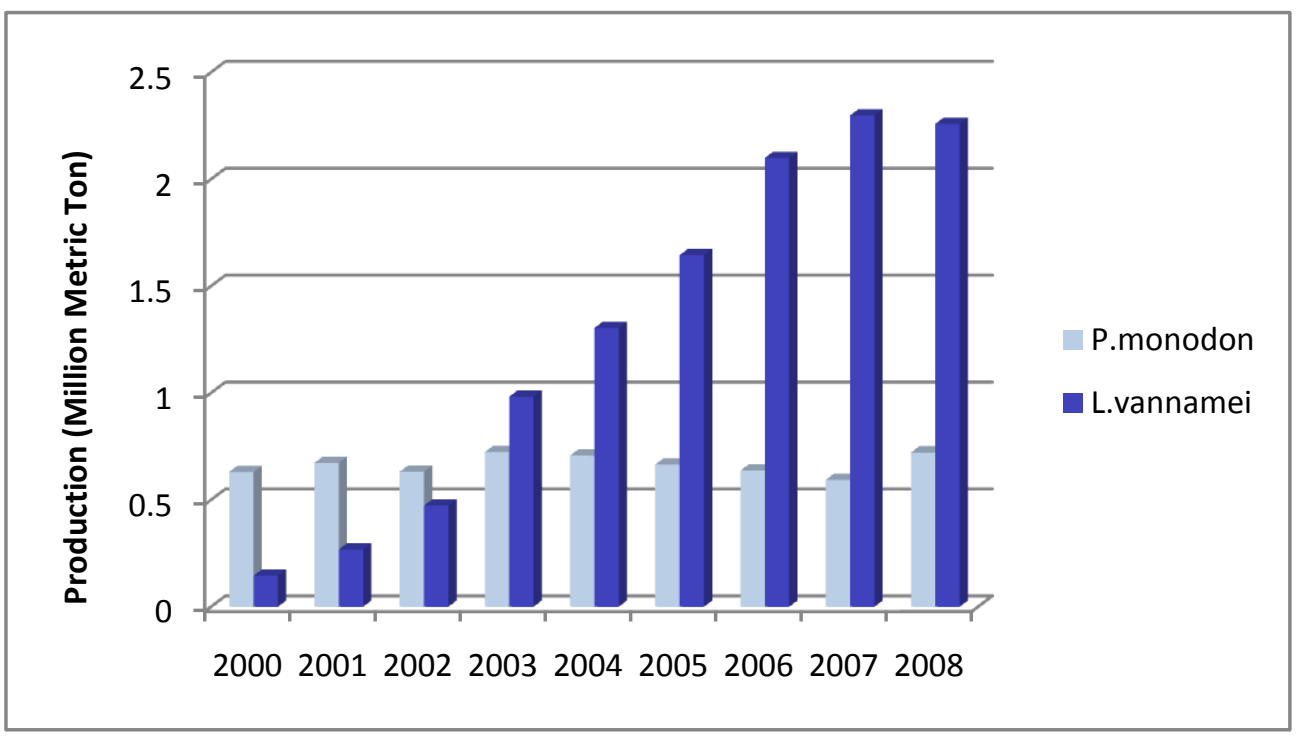

Fig. 1. Global production (metric tons) of farmed P. monodon and L. vannamei from 2000-2008.

\section{Specific Pathogen Free Shrimp}

Litopenaeus vannamei is native to the Eastern Pacific Ocean, from Mexico to Northern Peru and has dominated shrimp farming in the Western Hemisphere for decades (Bailey-Brock and Moss 1992). This species initially was introduced into 
Taiwan and China for commercial purposes in the late 1990s and its culture spread rapidly to Southeast Asia (Briggs et al. 2005). There are a number of advantages in culturing L. vannamei over P. monodon, including a lower dietary protein requirement, ease of captive reproduction and the commercial availability of healthy and domesticated stocks. This latter attribute is especially important in light of recent problems faced by $P$. monodon farmers.

Unlike many vannamei farmers, monodon farmers typically do not have access to an adequate and predictable supply of healthy and domesticated postlarvae to stock their ponds because postlarvae are either caught from the wild or produced from wildcaught broodstock. Wild shrimp often are infected with bacterial or viral pathogens which can be transmitted to non-infected shrimp. In contrast, commercially available populations of healthy and domesticated L. vannamei exist throughout the Americas and more recently in Asia, and these populations may be specific pathogen free (SPF). SPF shrimp are free of specific disease-causing agents (Lightner et al. 2009) and there are three essential criteria that need to be met for a pathogen to be considered for inclusion on an SPF list. These are: 1) the pathogen can be reliably diagnosed, 2) the pathogen can be physically excluded from a facility, and 3) the pathogen poses a significant threat to the industry. Although there is no internationally recognized SPF list used by the global shrimp farming industry, there are SPF L. vannamei suppliers who provide shrimp that are certifiably free of white spot syndrome virus (WSSV), yellow head virus (YHV), infectious hypodermal and hematopoietic necrosis virus (IHHNV), Taura syndrome virus (TSV) and infectious myonecrosis virus (IMNV). These viral pathogens have cost the global shrimp farming industry billions of dollars in lost crops, jobs and export revenue over the past decade. The current working list of specific pathogens for SPF penaeid shrimp used by the U.S. Marine Shrimp Farming Program includes eight groups of virus, two prokaryotes and certain classes of parasitic protozoa (Table 1). It is important to note that this list is dynamic and will be revised and expanded as new pathogens are identified and more accurate disease diagnostic tools become available. The importance of using SPF shrimp cannot be understated as they offer clear advantages over diseased shrimp or shrimp with undetermined disease status (Lightner et al. 2009; Wyban 2009).

The first population of SPF L. vannamei was developed by the U.S. Marine Shrimp Farming Program in the early 1990s (Wyban et al. 1993; Lotz et al. 1995; Lightner et al. 2009). In general, to develop SPF stocks from the wild, shrimp are collected and transferred to a primary quarantine facility where they are analyzed for specifically listed pathogens using appropriate disease diagnostic tools (Fig. 2; Moss et al. 2001; Lightner et al. 2009). If shrimp test positive for any of the listed pathogens, they are destroyed in the primary quarantine facility. If shrimp test negative for specifically 
Table 1. Recommended working list of specific pathogens for "SPF" penaeids in 2010-2011 (modified from Lightner et. al. 2009).

\begin{tabular}{|c|c|c|}
\hline Pathogen & Pathogen Type & Category \\
\hline \multicolumn{3}{|l|}{ VIRUSES } \\
\hline TSV & Dicistrovirus (n.f.) & $\mathrm{C}-1^{*}$ \\
\hline WSSV & Nimavirus (n.f.) & $\mathrm{C}-1 *$ \\
\hline YHV. GAV. LOV & Ronivirus (n.f.) & $\mathrm{C}-1,2^{*}$ \\
\hline IHHNV & Parvovirus & $\mathrm{C}-2 *$ \\
\hline MBV. BP. BMN & Crustacean baculoviruses & $\mathrm{C}-2 * * *$ \\
\hline IMNV & Totivirus & $\mathrm{C}-1,2^{*}$ \\
\hline $\mathrm{HPV}$ & Parvovirus & $\mathrm{C}-2$ \\
\hline PvNV & Nodavirus & $\mathrm{C}-3$ \\
\hline \multicolumn{3}{|l|}{ PROCARYOTES } \\
\hline NHP & Alpha proteobacteria & $\mathrm{C}-2 *$ \\
\hline RLB-MHD & MHD (rickettsial-like bacteria) & $\mathrm{C}-2 * *$ \\
\hline \multicolumn{3}{|l|}{ PROTOZOA } \\
\hline Microsporidians & Microsporidia & $\mathrm{C}-2$ \\
\hline Haplosporidians & Haplosporidia & $\mathrm{C}-2$ \\
\hline Gregarines & Apicomplexa & $\mathrm{C}-3$ \\
\hline
\end{tabular}

listed pathogens after several successive screenings, they are transferred to a secondary quarantine facility where they are matured and spawned to produce an $F_{1}$ generation of captive shrimp. Representative shrimp from the $F_{1}$ generation are then analyzed for specifically listed pathogens and if they test negative after several successive screenings, they are transferred out of the secondary quarantine facility and can be included as part of the germplasm in a genetic nucleus (GN) used in a selective breeding program. Shrimp that are maintained in a highly biosecure GN (i.e. where there is a history of negative disease status documented through a surveillance program) may be designated as SPF (Lotz 1997). However, once shrimp leave such a facility, they no longer are referred to as SPF even though they may be free of specifically listed pathogens. The new designation is High Health $(\mathrm{HH})$ shrimp and this indicates that 
these shrimp are at greater risk of pathogen exposure and infection (Lotz 1997). If shrimp are transferred to a low-biosecurity shrimp farm, they have entered the Commodity Production (CP) stream which is most vulnerable to pathogen outbreaks and the shrimp are neither SPF nor HH. An important point is that the SPF designation refers to present pathogen status only and is a function of where the shrimp are maintained (i.e. the level of biosecurity and disease history of the facility).

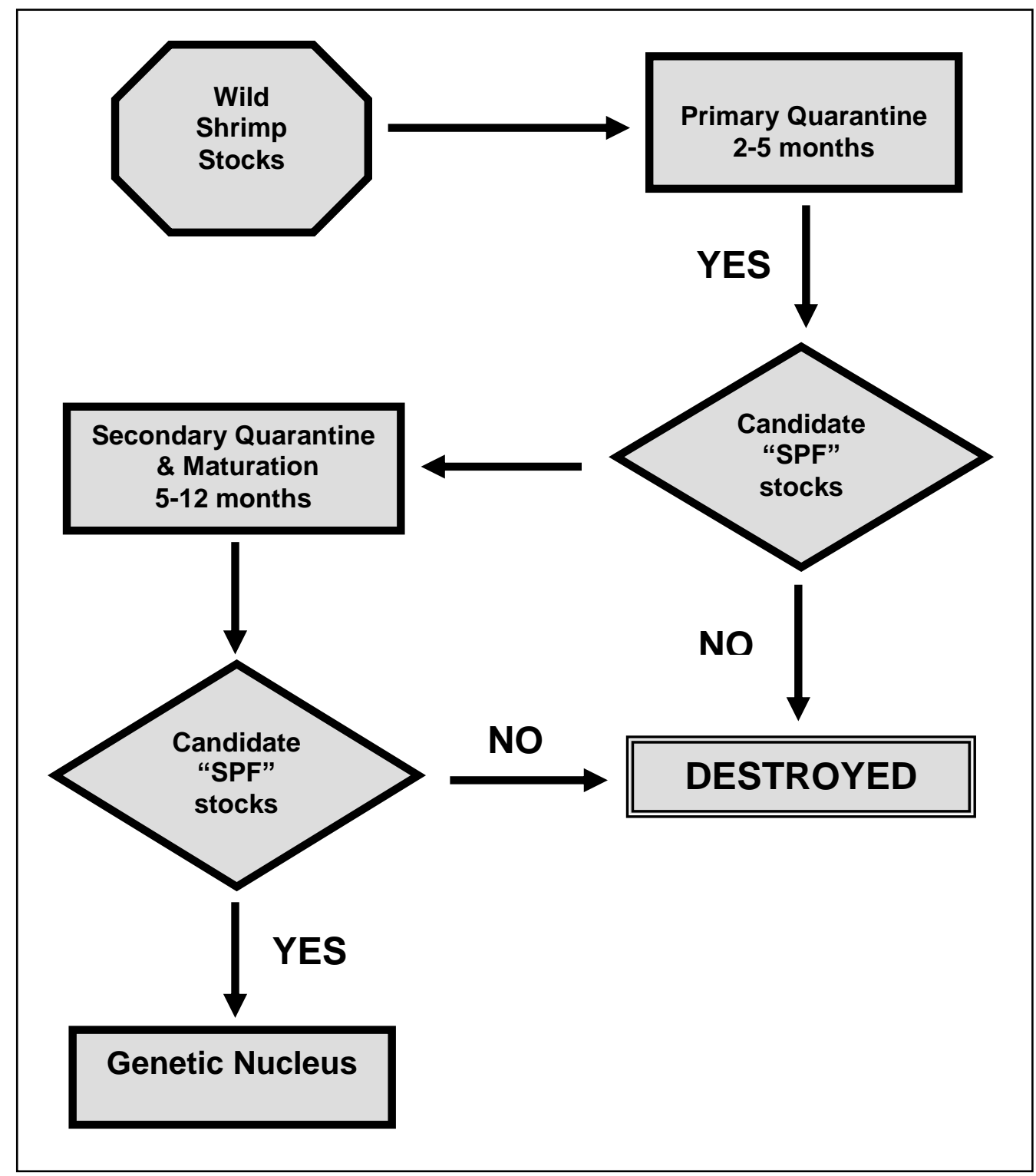

Fig. 2. Steps used to develop Specific Pathogen free (SPF) shrimp (see text for explanation; modified from Carr et al. 1994). 
Although SPF shrimp are by definition, free of all specifically listed pathogens, SPF shrimp may not be disease free. They may, for example, be infected with a known pathogen which is not included on the SPF list of the shrimp supplier or they may be infected with an unknown pathogen that has not yet been described. Interestingly, although some bacteria of the genus Vibrio can cause significant disease problems and can be reliably diagnosed (two of the essential criteria that need to be met for a pathogen to be considered for inclusion on an SPF list), they cannot be included on an SPF list. This is because they cannot be physically excluded from a facility due to the fact that they are ubiquitous members of the shrimp's normal flora. Finally, SPF shrimp have no innate resistance to a particular pathogen nor are they innately susceptible. Disease resistance or susceptibility can be bred into a line of shrimp through selective breeding or other approaches but this has no bearing on SPF status. SPF status is not an indication of the shrimp's genotype nor is it a heritable trait.

\section{Selective Breeding}

Another significant advantage in culturing L. vannamei is the opportunity to benefit from selective breeding. There are a number of shrimp breeding programs that produce and distribute $L$. vannamei which have been selectively bred for rapid growth. Faster growth will either increase the number of crops per year, thereby increasing

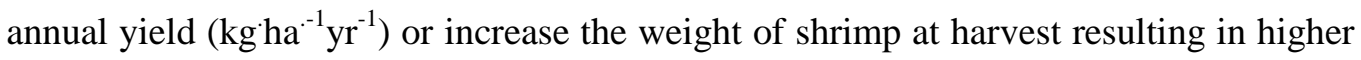
prices per $\mathrm{kg}$ for the farmer. Selecting for faster growth also may improve other commercially important traits by indirect selection such as feed conversion efficiency (Goyard et al. 2002) and pond survival (Gitterle et al. 2005a).

Heritability estimates $\left(h^{2}\right)$ for growth and size-related traits (i.e. weight, length, growth rate, etc.) have been reported in L. vannamei (Table 2; Carr et al. 1997; Argue et al. 2002; Pérez-Rostro and Ibarra 2003a, Gitterle et al. 2005a). In general, $h^{2}$ estimates for growth are considered moderate to high $\left(h^{2} \geq 0.2\right)$ and this trait has responded well to selection. For example, Argue et al. (2002) reported that selected L. vannamei were $21 \%$ and $23 \%$ larger at harvest than unselected control shrimp after one generation of selection when reared in a raceway and pond, respectively. More recently, Otoshi et al. (2009) reported that selectively bred L. vannamei stocked in a $75 \mathrm{~m}^{2}$ raceway at a density of 408 shrimp $\mathrm{m}^{-2}$ grew $1.88 \mathrm{~g}^{\cdot \mathrm{wk}^{-1}}$ over a 74 days period. Such rapid growth at such a high stocking density was unachievable a decade ago but is now possible due to selective breeding for rapid growth over multiple generations. 
Table 2. Heritability estimates $\left(h^{2} \pm \mathrm{SE}\right)$ for growth- and size-related traits in L. vannamei.

\begin{tabular}{llc}
\hline \multicolumn{1}{c}{ Trait } & $\boldsymbol{h}^{2} \pm \mathbf{S E}$ & Reference \\
\hline weight at $\sim 11 \mathrm{~g}$ & $0.42 \pm 0.15$ & Carr et al. 1997 \\
weight at $\sim 23 \mathrm{~g}$ & $0.84 \pm 0.43$ (raceway) & Argue et al. 2002 \\
& $1.19 \pm 0.59$ (pond) & \\
weight at $29 \mathrm{wk}$ & $0.34 \pm 0.18$ & Pérez-Rostro and Ibarra (2003a) \\
total length at 29 wk & $0.28 \pm 0.18$ & Pérez-Rostro and Ibarra \\
& & (2003a) \\
weight at $\sim 20 \mathrm{~g}$ & $0.24 \pm 0.05$ (line 1) & Gitterle et al. 2005a \\
& $0.17 \pm 0.04$ (line 2) & \\
\hline
\end{tabular}

Growth (and other commercially important traits) may be affected by the interaction between an organism's genotype and its environment ( $\mathrm{G} \times \mathrm{E}$ interaction). If these interactions are significant, breeders may need to develop different lines of shrimp for each unique rearing environment. There is little published data on $\mathrm{G} \times \mathrm{E}$ interactions for growth in penaeid shrimp, although Gitterle et al. (2005a) reported a low genotype by test environment interaction for harvest weight in L. vannamei reared in ponds and tanks. Similarly, Pérez-Rostro and Ibarra (2003b) reported an insignificant $\mathrm{G} \times \mathrm{E}$ interaction for harvest size in L. vannamei. These data suggest that shrimp which grow well in one environment will also grow well in other environments. The lack of a significant $\mathrm{G} \times \mathrm{E}$ interaction precludes the need to develop multiple fast-growing shrimp lines for different rearing conditions. However, there may be a significant $\mathrm{G} \times \mathrm{E}$ interaction for growout survival and additional research is needed to explore this relationship.

In addition to selecting for growth, shrimp breeders have focused their efforts on developing families of L. vannamei with enhanced resistance to TSV and WSSV (Argue et al. 2002; Jiang et al. 2004; Gitterle et al. 2005b) because these two viruses have had a significant economic impact on the global shrimp farming industry. Selective breeding for TSV resistance began in the mid 1990s in response to a TSV epizootic in Ecuador and the subsequent spread of TSV throughout the Americas. This virus has now spread to and impacted major shrimp farming regions in Asia (Tu et al. 1999; Phalitakul et al. 2006). TSV can infect juvenile shrimp within 2 to 4 wk after stocking into nurseries or growout ponds and cumulative mortalities of unselected shrimp in TSV-infected ponds have been reported to be as high as 80-90\% (Brock et al. 1997; Lightner et al. 1998).

Unlike growth, $h^{2}$ estimates for TSV resistance are considered low to moderate $\left(h^{2} \leq 0.2\right.$, Argue et al. 1999; Argue et al. 2002). However, despite low to moderate $h^{2}$, 
significant improvements in TSV resistance have been made through selection. For example, Moss et al. (2011) reported selection responses of 10-20\% per generation (expressed as the relative increase in survival when shrimp were exposed to TSV in a per os challenge) during the first several years of selection. There are now commercially available families of $L$. vanname $i$ which exhibit $>80 \%$ survival after TSV exposure and such a high level of survival was unimaginable when the initial TSV outbreak occurred in Ecuador in 1992.

The ability to improve TSV resistance by selection (despite low to moderate $h^{2}$ ) is attributed, in part, to high phenotypic/genotypic variation in TSV survival. This variation allows for a larger selection differential (and higher selection intensity) which increases the selection response. Argue et al. (2002) reported that TSV survival ranged from $15 \%$ to $94 \%$ among $80 \mathrm{~L}$. vannamei families exposed to TSV in a per os laboratory-challenge test. Similarly, White et al. (2002) reported that TSV survival ranged from $0 \%$ to $100 \%$ among 176 families that were challenged. Although large variations in family survival after TSV exposure have been observed among populations of L. vannamei, the magnitude of this variation can decline as selection progresses. For example, whereas mean family survival increased from $44 \%$ to $84 \%$ after five generations of selection for TSV resistance among a population of $L$. vannamei families maintained at Oceanic Institute (OI, Waimanalo, Hawaii, USA), the coefficient of variation (CV) for TSV survival decreased from $43.3 \%$ and $13.6 \%$ (Fig. 3 ). This reduction in variability is expected as selection progresses and will result in progressively lower selection responses (Falconer and Mackay 1996).

In addition to developing families of shrimp with enhanced TSV resistance, shrimp breeders have explored the possibility of selecting shrimp for resistance to WSSV. Limited research suggests that $h^{2}$ estimates for WSSV resistance are lower than those reported for TSV. Published $h^{2}$ estimates for WSSV resistance in $L$. vannamei range from 0.00 to 0.21 and most estimates are $<0.1$ (Gitterle et al. 2005b, 2006a, 2006b). Thus, only small improvements in WSSV resistance have been made in L. vannamei through selection. For example, Gitterle et al. (2005b) reported a mean selection response of only $2.8 \%$ after one generation of selection for WSSV resistance in a population of L. vannamei. In contrast, Huang et al. (2010) recently reported producing families of L. vannamei with a mean survival of $22.7 \%$ to WSSV infection after three generations of selection. These researchers also reported that the relatively resistant families appeared to be able to inhibit WSSV replication in muscle tissue. 


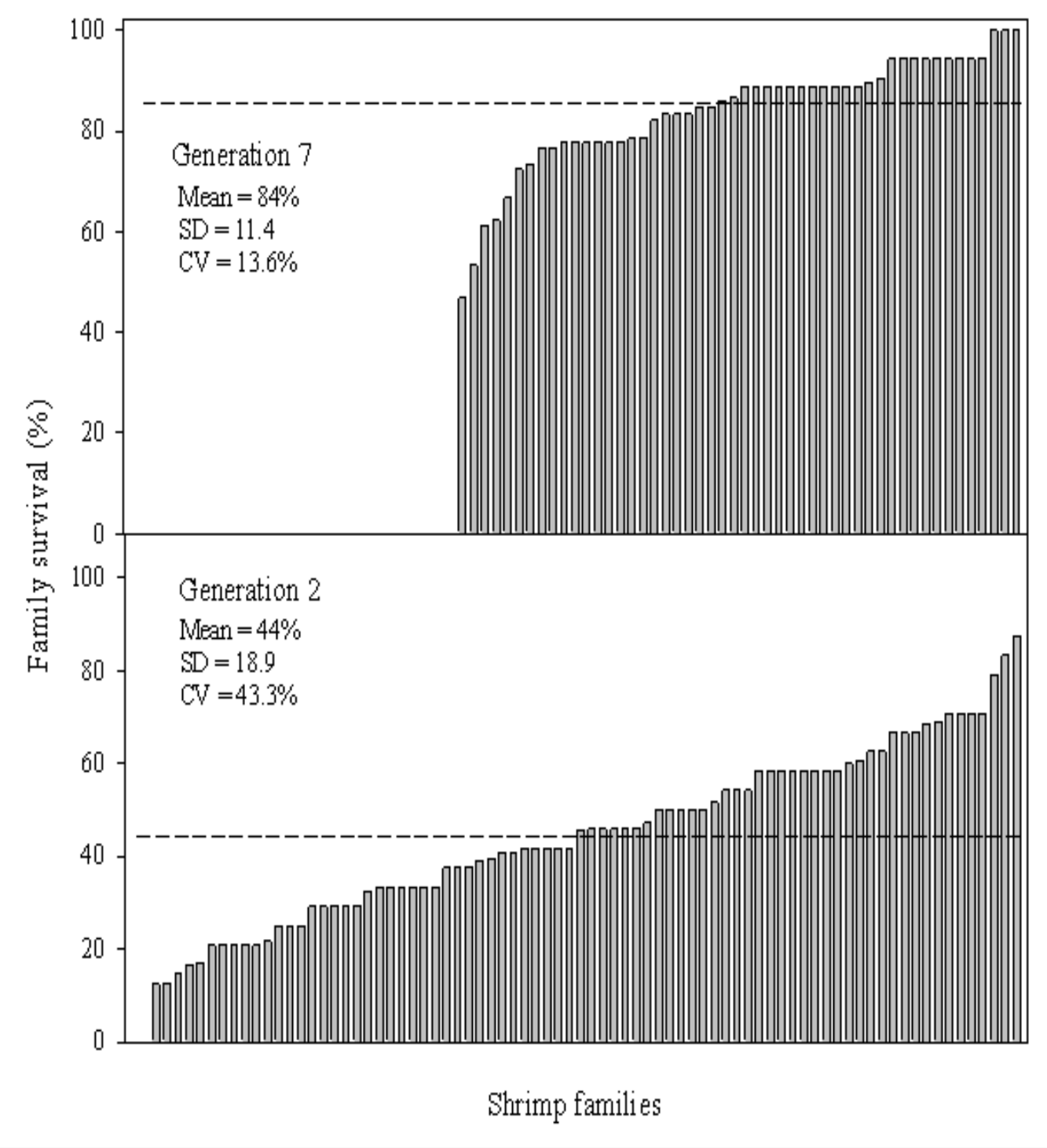

Fig. 3. Phenotypic variation in family survival for a population of shrimp at Oceanic Institute (Waimanalo, Hawaii, USA) after two and seven generations of selection for TSV resistance. Each bar represents a family mean, and the dashed line represents mean family survival for the entire population (mean of family means).

There are a number of other shrimp pathogens which negatively impact the global shrimp farming industry. However, these pathogens have received little or no attention from shrimp breeders to date. Breeding shrimp for disease resistance is a costly and lengthy process and is justified only if a pathogen has a significant economic impact on the industry and there are no cost-effective measures to prevent or treat infection. In addition, there must be sufficient additive genetic variation in resistance to the pathogen under selection (i.e. the trait must be heritable) for selection to work, and there must be reliable disease-challenge protocols developed if a family-based breeding 
program is to be used to enhance disease resistance. Finally, it is important to note that each additional trait added to a selection program will result in slower progress (i.e. smaller selection response per generation) for all selected traits, even if the traits are positively correlated. This restriction puts an upper limit on the number of traits that can be reasonably selected for in a given shrimp line.

\section{Biofloc Technology}

Traditionally, penaeid shrimp have been cultured in coastal, earthen ponds where flow-through water exchange is used to maintain acceptable water quality (Hopkins et al. 1993). However, influent water can serve as a vector for virulent pathogens (Lotz 1997; Lotz and Lightner 2000) and pond effluent can adversely affect coastal water quality (Goldburg and Triplett 1997). Biofloc technology (BFT) offers an alternative approach to traditional shrimp farming methods. With BFT, water is remediated by an in situ microbial community that grows on suspended water-column particles and on biofilms attached to surfaces. This approach results in a dramatic reduction in water use which minimizes the opportunity for pathogen introduction into the shrimp culture environment. With this level of biosecurity, the genetic potential of selectively bred shrimp can be realized.

In addition to the biosecurity benefits, BFT-managed systems typically are stocked at super-intensive densities $\left(>300\right.$ shrimp $^{-2}$ ) and these systems may be enclosed in greenhouse structures where optimal temperatures can be maintained. Super-intensive densities and temperature control allow for year-round production and requires a much smaller footprint. A BFT facility can be sited at inland locations away from sensitive coastal areas where multiple-use conflicts exist and at temperate latitudes closer to major markets, thereby reducing transport costs and the number of "food miles" (which is a measure of environmental impact).

Researchers at OI in Hawaii have conducted studies on BFT shrimp production systems since 1997 and numerous trials have been conducted in research-sized $\left(33 \mathrm{~m}^{2}\right.$ $75 \mathrm{~m}^{2}$ ), greenhouse-covered raceways. Stocking densities have ranged from 100 to 700 shrimp m ${ }^{-2}$ and production of $8.9 \mathrm{kgm}^{-2}$ was achieved in a $58.4 \mathrm{~m}^{2}$ BFT system (Moss et al. 2005). Uncertainties remained regarding potential scale-up issues which may arise when transferring this technology from a research to a commercial-sized system. In an effort to address this concern, the first trial conducted at OI in a commercial-sized (337 $\mathrm{m}^{2}$ ) system was completed in 2007 and the stocking density was increased to 828 shrimp $\mathrm{m}^{-2}$. Trial results included $18.3 \mathrm{~g}$ harvest weight, $67.9 \%$ survival, $1.5 \mathrm{~g} \mathrm{wk}^{-1}$ growth rate and $2.1 \% \mathrm{day}^{-1}$ water exchange rate. There were no significant scale-up issues encountered and production of $10.3 \mathrm{~kg}^{-2}$ was achieved (Otoshi et al. 2007). Importantly, shrimp bred for rapid growth and high survival under conditions specific 
to BFT (i.e. super-intensive densities, high water-column bacterial concentrations and high carbon dioxide and nitrite concentrations) were used in this trial, and these selectively bred shrimp likely played a significant role in achieving high production.

The two most recent growout trials using OI's selectively bred shrimp were conducted in a $75 \mathrm{~m}^{2}$ BFT system stocked at densities of 363 and 300 shrimp m ${ }^{-2}$, respectively. For these trials, production was 5.8 and $5.3 \mathrm{~kg} \mathrm{~m}^{-2}$, survival was 90.3 and $87.1 \%$ and growth rate was 1.67 and $1.59 \mathrm{~g} \mathrm{wk}^{-1}$, respectively. Water usage was 219 and $304 \mathrm{Lkg}^{-1}$ shrimp produced and water exchange was 0.3 and $0.6 \% \mathrm{day}^{-1}$, respectively. Results from these trials demonstrate that the use of selectively bred shrimp and improved system design and management of the BFT system can result in excellent shrimp performance at high stocking densities.

Commercial production of shrimp requires consistency and predictability to adequately meet market demand. Results from the growout trials conducted at OI demonstrate that high shrimp production can be achieved consistently using BFT when stocked at densities ranging from 300 to 400 shrimp $\mathrm{m}^{-2}$. Furthermore, a trial conducted

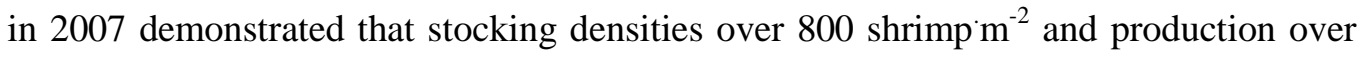
$10 \mathrm{~kg} \mathrm{~m}^{-2}$ are possible in a commercial-scale system. Through continued research and development, a more comprehensive understanding of BFT system design and management has developed. Further improvements in production efficiencies (i.e. simplification of system design, improved management and continued selective breeding) likely will reduce production costs even further, thereby removing a significant barrier to the commercial viability of this alternative shrimp growout technology.

\section{An Integrated Approach}

The use of SPF, selectively bred L. vannamei, coupled with on-farm biosecurity protocols such as BFT, provides the best opportunity for increased production, profitability and sustainability for shrimp farmers. This strategy has been employed most pervasively in Thailand which ranks as one of the world's most important producers of farmed shrimp. In 2001, monodon farmers in Thailand began observing a phenomenon now referred to as monodon slow-growth syndrome (MSGS) which is characterized by abnormally slow growth rates and unusually high size variation at harvest. Although the etiology of MSGS remains unclear, its ramifications are unequivocal. MSGS in combination with other factors, rendered monodon farming in Thailand unprofitable and resulted in estimated financial losses of approximately US\$310 million in 2002 (Chayaburakul et al. 2004). Since then, most Thai farmers have switched to culturing SPF, selectively bred $L$. vannamei and have enjoyed the 
benefits of better production efficiencies and higher profits. Wyban (2009) recently reported that vannamei farmers in Thailand have profit margins two to three times greater than monodon farmers (Table 3) and that by 2006 L. vannamei represented over $98 \%$ of farmed shrimp entering the Thai shrimp auction. On a broader scale, current estimates suggest that L. vannamei represents $76 \%$ of farmed shrimp in Asia and this number is projected to increase.

Table 3. Production parameters and profits for a typical shrimp farm in Thailand culturing $P$. monodon and L. vannamei, respectively (modified from Wyban 2009).

\begin{tabular}{lccc}
\hline Parameter & P. monodon & L. vannamei & \% Difference \\
\hline Density $\left(\mathrm{PL} \mathrm{m}^{-2}\right)$ & 45 & 160 & +256 \\
Crop duration (days) & 125 & 112 & -10 \\
Harvest size $(\mathrm{g})$ & 25 & 23 & -8 \\
Yield (MT $\left.\mathrm{ha}{ }^{-1} \mathrm{crop}^{-1}\right)$ & 8 & 24 & +200 \\
Crop value $\left(\mathrm{US} \$ \mathrm{ha}^{-1}\right)$ & $\$ 45000$ & $\$ 96000$ & +113 \\
Crop costs $\left(\mathrm{US} \$ \mathrm{ha}^{-1}\right)$ & $\$ 32000$ & $\$ 60000$ & +87.5 \\
Production profit $\left(\mathrm{US} \$ \mathrm{ha}^{-1}\right)$ & $\$ 13000$ & $\$ 36000$ & +177 \\
\hline
\end{tabular}

Although the benefits associated with culturing SPF, selectively bred $L$. vannamei in Asia have been significant, the importation of this species has created some problems. As with the importation of any non-indigenous species, there are concerns about the introduction and spread of exotic pathogens. History is replete with examples of exotic introductions in aquaculture and the worldwide shipment of live and frozen shrimp has served as an important vector for the trans-global movement of virulent viral pathogens including the relatively recent introduction of IMNV from Brazil into Asia. Importing countries should continue to require foreign broodstock suppliers to provide documentation about the SPF status of their shrimp, although illegal smuggling of non-SPF L. vannamei likely will continue as well. In addition to ensuring the importation of healthy shrimp, care must be taken by importing countries to ensure that founder stocks come from genetically diverse populations of $L$. vannamei. If not, problems associated with inbreeding depression may arise, resulting in reduced production and profitability. The long-term success of the global shrimp farming industry will be predicated on the use of genetically diverse and selectively bred populations of SPF shrimp stocked into controlled and biosecure environments.

\section{References}

Argue, B.J., S. Arce, J. Lotz and S. Moss. 1999. Heritability for resistance to Taura syndrome virus in specific pathogen free Litopenaeus vannamei. World Aquaculture '99, Book of Abstracts, Sydney, Australia, World Aquaculture Society. pp. 28. 
Argue, B.J., S.M. Arce, J.M. Lotz and S.M. Moss. 2002. Selective breeding of Pacific white shrimp Litopenaeus vannamei for growth and resistance to Taura syndrome virus. Aquaculture 204:447-460.

Bailey-Brock, J.H. and S.M. Moss. 1992. Penaeid taxonomy, biology and zoogeography. In: Marine shrimp culture: principles and practices (ed. A.W. Fast and L.J. Lester), pp. 927. Elsevier Science Publishers, New York.

Briggs, M., S. Funge-Smith, R.P. Subasinghe, and M. Phillips. 2005. Introductions and movement of two penaeid shrimp species in Asia and the Pacific. FAO Fisheries Technical Paper, Rome. No. 476. 78 pp.

Brock, J. A., R.B. Gose, D.V. Lightner and K. Hasson. 1997. Recent developments and an overview of Taura syndrome of farmed shrimp in the Americas. In: Diseases in Asian aquaculture III (eds. T.W. Flegel and I.H. MacRae), pp. 275-284. Fish Health Section, Asian Fisheries Society, Manila, Philippines.

Carr, W.H., J.N. Sweeney and J.S. Swingle. 1994. The Oceanic Institute's specific pathogen free (SPF) shrimp breeding program: preparations and infrastructure. USMSFP $10^{\text {th }}$ Anniversary Review, GCRL Special Publication, No. 1. pp. 47-54.

Carr, W.H., K.T Fjalestad, D. Godin, J. Swingle, J.N. Sweeney and T. Gjedrem. 1997. Genetic variation in weight and survival in a population of specific pathogen-free shrimp Penaeus vannamei. In: Diseases in Asian aquaculture III (eds. T.W. Flegel and I.H. MacRae), pp. 265-271. Fish Health Section, Asian Fisheries Society, Manila, Philippines.

Chayaburakul, K., G. Nash, P. Pratanpipat, S. Sriurairatana and B. Withyachumnarnkul. 2004. Multiple pathogens found in growth retarded black tiger shrimp Penaeus monodon cultivated in Thailand. Diseases of Aquatic Organisms 60:89-96.

Falconer, D.S. and T.F.C. Mackay. 1996. Introduction to quantitative genetics, $4^{\text {th }}$ edition, Logman Group, Essex, England.

FAO (Food and Agriculture Organization). 2010, www.fao.org/figis.

Gitterle, T., M. Rye, R. Salte, J. Cock, H. Johansen, C. Lozano, J.A. Suárez, and B. Gjerde. 2005a. Genetic (co) variation in harvest body weight and survival in Penaeus (Litopenaeus) vannamei under standard commercial conditions. Aquaculture 243:8392.

Gitterle,T., R. Salte, B. Gjerde, J. Cock, H. Johansen, M. Salazar, C. Lozano and M. Rye. 2005b. Genetic (co)variation in resistance to White Spot Syndrome Virus (WSSV) and harvest weight in Penaeus (Litopenaeus) vannamei. Aquaculture 246:139-149.

Gitterle, T., B. Gjerde, J. Cock, M. Salazar, M. Rye, O. Vidal, C. Lozano, C. Erazo and R. Salte. 2006a. Optimization of experimental infection protocols for the estimation of genetic parameters of resistance to White Spot Syndrome Virus (WSSV) in Penaeus (Litopenaeus) vannamei. Aquaculture 26:501-509.

Gitterle, T., J. Ødegård, B. Gjerde, M. Rye and R. Salte. 2006b. Genetic parameters and accuracy of selection for resistance to White Spot Syndrome Virus (WSSV) in Penaeus (Litopenaeus) vannamei using different statistical models. Aquaculture 25:210-218.

Goldburg, R. and T. Triplett. 1997. Murky waters: environmental effects of aquaculture in the United States. The Environmental Defense Fund, EDF Publications, Washington, D.C. 196 pp. 
Goyard, E., J. Patrois, J.M. Peignon, V. Vanaa, R. Dufour, J. Viallon and E. Bédier. 2002. Selection for better growth of Penaeus stylirostris in Tahiti and New Caledonia. Aquaculture 204:461-468.

Hopkins, J.S., R.D. Hamilton, P.A. Sandifer, C.L. Browdy and A.D. Stokes. 1993. Effect of water exchange rate on the production, water quality, effluent characteristics and nitrogen budgets in intensive shrimp ponds. Journal of the World Aquaculture Society 24:304-320.

Huang, Y.C., Z.X. Yin, H.S. Ai, X.D. Huang, S.D. Li, S.P. Weng and J.G. He. 2010. Characterization of WSSV resistance in selected families of Litopenaeus vannamei. Aquaculture 311:54-60.

Jiang, D., J.L. Rocha, D. Ciobanu, A. Mileham, H. van der Steen, B.L. White-Noble and D.V. Lightner. 2004. Quantitative, molecular genetic selection for shrimp disease resistance. Global Aquaculture Advocate, February:52-55.

Lightner, D. V., R.M. Redman, B.T. Poulos, L.M. Nunan, L.H. Mohney, L.J. Mari, K.W. Hasson, R.C. Pantoja, K.T. Nelson, J.L. Zhou, Q. Wang, J. Garza and B.L. White. 1998. Viral diseases of shrimp in the Americas: diagnosis, distribution, and control strategies. In: Proceedings of the First Latin American Shrimp Farming Congress (ed. D.E. Jory), pp. 1-10. Panama City, Panama.

Lightner, D.V., R.M. Redman, S.M. Arce and S.M. Moss. 2009. Specific pathogen free shrimp stocks in shrimp farming facilities as a novel method for disease control in crustaceans. In: Shellfish safety and quality (eds. S.E. Shumway and G.E. Rodrick), pp. 384-424. CRC Press, Woodhead Publishing Limited, Cambridge, England.

Lotz, J.M. 1997. Disease control and pathogen status assurance in an SPF-based shrimp aquaculture industry, with particular reference to the United States. In: Diseases in Asian aquaculture III (eds. T.W. Flegel and I.H. MacRae), pp. 243-254. Fish Health Section, Asian Fisheries Society, Manila, Philippines.

Lotz, J.M. and D.V. Lightner. 2000. Shrimp biosecurity: pathogens and pathogen exclusion. In: Controlled and biosecure production systems, Proceedings of a Special Session Integration of Shrimp and Chicken Models (eds. R.A. Bullis and G.D. Pruder), pp. 6774. Oceanic Institute, Waimanalo, Hawaii, USA.

Lotz, J.M., C.L. Browdy, W.H. Carr, P.F. Frelier and D.V. Lightner. 1995. USMSFP suggested procedures and guidelines for assuring the specific pathogen status of shrimp broodstock and seed. In: Swimming through troubled water, Proceedings of the Special Session on Shrimp Farming. (eds. C.L. Browdy and J. S. Hopkins), pp. 66-75. World Aquaculture Society, Baton Rouge, Louisiana.

Moss, D.M., S.M. Arce, C.A. Otoshi and S.M. Moss. 2011. Shrimp breeding for resistance to Taura syndrome virus. Global Aquaculture Advocate 14(1):40-41.

Moss, S.M., C.A. Otoshi and P. Leung. 2005. Bigger shrimp: optimizing strategies for growing larger L. vannamei. Global Aquaculture Advocate 8(5):68-69.

Moss, S.M., S.M. Arce, B.J. Argue, C.A. Otoshi, F.R.O. Calderon and A.G.J. Tacon. 2001. Greening of the blue revolution: efforts toward environmentally responsible shrimp culture. In: The new wave, Proceedings of the Special Session on Sustainable Shrimp Farming (eds. C.L. Browdy and D.E. Jory), pp. 1-19. World Aquaculture Society, Baton Rouge, Louisiana. 
Otoshi, C.A., S.S. Naguwa, F.C Falesch and S.M. Moss. 2007. Commercial-scale RAS trial yields record shrimp production for Oceanic Institute. Global Aquaculture Advocate 10(6):74-76.

Otoshi, C.A., L.R. Tang, D.R. Moss, S.M. Arce, C.M. Holl and S.M. Moss. 2009. Performance of Pacific white shrimp, Penaeus (Litopenaeus) vannamei, cultured in biosecure, superintensive, recirculating aquaculture systems. In: The rising tide, Proceedings of the Special Session on Sustainable Shrimp Farming (eds. C.L. Browdy and D.E. Jory), pp. 244-254. The World Aquaculture Society, Baton Rouge Louisiana, USA.

Pérez-Rostro, C. I. and A.M. Ibarra. 2003a. Heritabilities and genetic correlations of size traits at harvest size in sexually dimorphic Pacific white shrimp (Litopenaeus vannamei) grown in two environments. Aquaculture Research 34:1079-1085.

Pérez-Rostro, C. I. and A.M. Ibarra. 2003b. Quantitative genetic parameter estimates for size and growth rate traits in Pacific white shrimp, Penaeus vannamei (Boone 1931) when reared indoors. Aquaculture Research 34:543-553.

Phalitakul, S., J. Wongtawatchai, M. Sarikaputi and N. Viseshakul. 2006. The molecular detection of Taura syndrome virus emerging with White spot syndrome virus in penaeid shrimps of Thailand. Aquaculture 260:77-85.

Tu, C., H.T. Huang, S.H. Chuang, J.P. Hsu, S.T. Kuo, J.N. Li, T.L. Hsu, M.C. Li and S.Y. Lin. 1999. Taura syndrome in Pacific white shrimp Penaeus vannamei cultured in Taiwan. Diseases of Aquatic Organisms 38:159-161.

White, B.V., P.L. Schofield, B.T. Poulos and D.V. Lightner. 2002. A laboratory challenge method for estimating Taura syndrome virus resistance in selected lines of Pacific white shrimp Litopenaeus vannamei. Journal of the World Aquaculture Society 33:341-348.

Wyban, J.A., J.S. Swingle, J.N. Sweeney and G.D. Pruder. 1993. Specific pathogen free Penaeus vannamei. World Aquaculture 24:39-45.

Wyban, J. 2009. World shrimp farming revolution: industry impact of domestication, breeding and widespread use of specific pathogen free Penaeus vannamei. In: The rising tide, Proceedings of the Special Session on Sustainable Shrimp Farming (eds. C.L. Browdy and D.E. Jory), pp. 12-21. The World Aquaculture Society, Baton Rouge Louisiana, USA. 